\title{
Properties of Large Conductance Calcium-Activated Potassium Channels in Pyramidal Neurons from the Hippocampal CA1 Region of Adult Rats
}

\author{
Liang-Wei GONG, Tian-Ming GAO*, Hao HUANG, and Zhenqing TONG \\ Department of Physiology, The First Military Medical University, Guangzhou, 510515, China P.R.
}

\begin{abstract}
The properties of large-conductance $\mathrm{Ca}^{2+}$-activated $\mathrm{K}^{+}\left(\mathrm{BK}_{\mathrm{Ca}}\right)$ channels were studied in rat hippocampal CA1 pyramidal neurons by using the patch-clamp technique in the excisedinside-out-patch configuration. The lowest $\left[\mathrm{Ca}^{2+}\right]_{i}$ in which $\mathrm{BK}_{\mathrm{Ca}}$ channel activities were observed was $0.01 \mu \mathrm{M}$ with the membrane potential of $+20 \mathrm{mV}$ and the $\left[\mathrm{Ca}^{2+}\right]_{\mathrm{i}}$ at which $P_{\mathrm{o}}$ of the channel is equal to 0.5 was $2 \mu \mathrm{M}$. The unitary conductance of the single $\mathrm{BK}_{\mathrm{Ca}}$ channel was $245.4 \mathrm{pS}$ with symmetrical $140 \mathrm{mM} \mathrm{K}^{+}$on both sides of the excised membrane. With a fixed $\left[\mathrm{Ca}^{2+}\right]_{i}$ of $2 \mu \mathrm{M}$, $P_{\text {o }}$ increased $e$-fold with a $17.0 \mathrm{mV}$ positive change in the membrane potential. Two exponentials, with time constants of $2.8 \mathrm{~ms}$ and $19.2 \mathrm{~ms}$ at the membrane potential of $+20 \mathrm{mV}$
\end{abstract}

with $2 \mu \mathrm{M}\left[\mathrm{Ca}^{2+}\right]_{\mathrm{i}}$, were required to describe the observed open time distribution of $\mathrm{BK}_{\mathrm{Ca}}$ channel, suggesting the existence of two distinct open channel states with apparently normal conductance. A BK $\mathrm{Ca}$ channel occasionally entered an apparent third open channel state with the single channel current amplitude about $45 \%$ of the normal amplitude. The properties of $\mathrm{BK}_{\mathrm{Ca}}$ channel, which were found in this study to be more steeply dependent on voltage and more sensitive to $\left[\mathrm{Ca}^{2+}\right]_{\mathrm{i}}$ in adult hippocampal neurons than in cultured or immature hippocampal neurons, may be responsible for the shortened duration of action potential in hippocampal CA1 pyramidal neurons of adult rat. [Japanese Journal of Physiology $51,725-731,2001]$

Key words: $\quad \mathrm{BK}_{\mathrm{Ca}}$ channel, pyramidal neuron, patch clamp, hippocampus, rat.

$\mathrm{Ca}^{2+}$-activated $\mathrm{K}^{+}$currents/channels have been described in a great many nonneuronal cells [1-4] and in neurons [5-13]. Single-channel studies have identified at least two types of channels $\left(\mathrm{BK}_{\mathrm{Ca}}\right.$ and $\mathrm{SK}_{\mathrm{Ca}}$, large conductance and small conductance $\mathrm{Ca}^{2+}$-activated $\mathrm{K}^{+}$channels) in neuronal membranes on the basis of their pharmacological and biophysical properties [14, 15]. In neurons in vivo, $\mathrm{BK}_{\mathrm{Ca}}$ channel is thought to be activated by $\mathrm{Ca}^{2+}$ ions entering the cell during the rising phase of the action potential and seems to be mainly responsible for the last two thirds of the spike repolarization and the fast after-hyperpolarization (fAHP) [16-18]. Evidence supporting this hypothesis is the findings that the spike broadens and the fAHP disappears when $\mathrm{BK}_{\mathrm{Ca}}$ channels are blocked by external administration of TEA $(0.5-1 \mathrm{mM})$ or $\mathrm{Ca}^{2+}$-chan- nel blockers, or by an intracellular injection of a fast $\mathrm{Ca}^{2+}$ chelator, BAPTA [14, 19-21].

In recent years, many data concerning $\mathrm{BK}_{\mathrm{Ca}}$ channel have been obtained by the use of patch clamp techniques in cultured or immature neurons [5-7, 9-14]. In contrast, most studies concerning the $\mathrm{BK}_{\mathrm{Ca}}$ channel's role in spike repolarization, and fAHP [16, $21,22]$ have used recordings from slices of adult brain or in vivo recordings. Little is known so far about the properties of the $\mathrm{BK}_{\mathrm{Ca}}$ channel in adult neurons. It is therefore desirable for the single channel properties of $\mathrm{BK}_{\mathrm{Ca}}$ channel to be studied also in adult neurons.

The experiments in this study were designed primarily to extend the observations on the properties of the individual $\mathrm{BK}_{\mathrm{Ca}}$ channel in CA1 pyramidal neurons from adult rat hippocampus.

Received on March 26, 2001; accepted on October 5, 2001

Correspondence should be addressed to: Tian-Ming Gao, Department of Physiology, The First Military Medical University, Guangzhou, 510515, P.R. China. Tel: +86-20-85148216, Fax: +86-20-87730321, E-mail: tgao@fimmu.edu.cn 


\section{MATERIALS AND METHODS}

Acute-dissociation procedures. Pyramidal cells in the hippocampal CA1 region from male adult rats (weighing 200-250 g) were acutely dissociated, using procedures described previously [23-25] with some modifications. In brief, rats were anesthetized with chloral hydrate (I.P., $40 \mathrm{mg} / 100 \mathrm{~g}$ body weight), then decapitated; brains were quickly removed, iced, and blocked for slicing. The blocked tissue was cut into $400 \mu \mathrm{m}$ slices with a Vibroslice while being bathed in a low $\mathrm{Ca}^{2+}(100 \mu \mathrm{M})$, HEPES-buffered salt solution containing (in mM) 140 sodium isethionate, 2 $\mathrm{KCl}, 4 \mathrm{MgCl}_{2}, 0.1 \mathrm{CaCl}_{2}, 23$ glucose, and 15 HEPES, $\mathrm{pH} 7.4(300-305 \mathrm{mOsm} / l)$. Slices were then incubated for $1-6 \mathrm{~h}$ at room temperature $\left(20-22^{\circ} \mathrm{C}\right)$ in an $\mathrm{NaHCO}_{3}$-buffered saline bubbled with $95 \% \mathrm{O}_{2} / 5 \%$ $\mathrm{CO}_{2}$ containing (in mM) $126 \mathrm{NaCl}, 2.5 \mathrm{KCl}, 2 \mathrm{CaCl}_{2}$, $2 \mathrm{MgCl}_{2}, 26 \mathrm{NaHCO}_{3}, 1.25 \mathrm{NaH}_{2} \mathrm{PO}_{4}, 1$ pyruvic acid, 0.005 glutathione, $0.1 \mathrm{~N}^{\omega}$-nitro-L-arginine, 1 kynurenic acid, and 10 glucose, pH 7.4 with $\mathrm{NaOH}$ (300-305 $\mathrm{mOsm} / l$ ). All reagents were obtained from Sigma (St. Louis, MO). Slices were then transferred into the low $\mathrm{Ca}^{2+}$ buffer, and the CA1 region of hipocampus was dissected out under a dissecting microscope and transferred to an oxygenated chamber containing pronase (Sigma protease Type XIV, $1-3 \mathrm{mg} / \mathrm{ml}$ ) in HEPESbuffered HBSS (Sigma) at $33^{\circ} \mathrm{C}$. After $30-45 \mathrm{~min}$ of enzyme digestion, the tissue was rinsed three times in the low $\mathrm{Ca}^{2+}$, HEPES-buffered saline and dissociated mechanically with a graded series of fire-polished Pasteur pipettes. The cell suspension was then transferred to a $35 \mathrm{~mm}$ Lux petri dish mounted on the stage of an inverted microscope containing HEPES-buffered HBSS saline. After allowing the cells to settle, the bathing solution was changed to the recording solution. All reagents were purchased from Sigma.

Single-channel current recording. Gigaseal patch recordings using the inside-out patch configuration as described by Hamill et al. [26] (the feedback resistor was $50 \mathrm{G} \Omega$ ) were performed on neurons with pyramidal shapes at room temperature. The pipette resistance was $8-12 \mathrm{M} \Omega$, and the seal resistance exceeded $3 \mathrm{G} \Omega$. Single-channel currents were recorded in excised inside-out patches, which were prepared by having the patch electrode pulled away from the pyramidal cells. The composition of the flow solution that bathed the intracellular face of the patch membrane after excision was (in $\mathrm{mM}$ ) $140 \mathrm{KCl}, 10 \mathrm{NaCl}$, and 10 HEPES. For solutions with a desired free calcium of less than $5 \mu \mathrm{M}, 500 \mu \mathrm{M}$ EGTA (ethyleneglycol-bis-( $\beta$ amino-ethylether) $\mathrm{N}_{2} \mathrm{~N}^{\prime}$-tetraacetic acid) and $\mathrm{CaCl}_{2}$ were added to the solution to obtain the desired level of total free calcium [27]. The desired free $\mathrm{Ca}^{2+}$ concentrations and the nominal $\mathrm{Ca}^{2+}$ concentration in the solution with $500 \mu \mathrm{M}$ EGTA were $0.01 \mu \mathrm{M}$ free $\mathrm{Ca}^{2+}$ and $55.7 \mu \mathrm{M} \mathrm{Ca}^{2+} ; 0.1 \mu \mathrm{M}$ free $\mathrm{Ca}^{2+}$ and $279 \mu \mathrm{M}$ $\mathrm{Ca}^{2+} ; 0.5 \mu \mathrm{M}$ free $\mathrm{Ca}^{2+}$ and $435 \mu \mathrm{M} \mathrm{Ca}^{2+}$; and $2 \mu \mathrm{M}$ free $\mathrm{Ca}^{2+}$ and $485 \mu \mathrm{M} \mathrm{Ca}^{2+}$. For a solution with a desired free $\mathrm{Ca}^{2+}$ of $5 \mu \mathrm{M}$ or higher, EGTA was omitted and $\mathrm{CaCl}_{2}$ was added as required. Solutions were adjusted to a final $\mathrm{pH}$ of 7.40. The pipette solution consisted of either the bathing solutions to give symmetrical charge-carrier distribution or a low concentration of $\mathrm{K}^{+}$solution $\left(5 \mathrm{mM} \mathrm{K}^{+}\right) . \mathrm{MgCl}_{2}$ at $0.5 \mathrm{mM}$ was routinely added to the pipette solution purely for easier seal formation in the absence of other divalent ions.

The single-channel currents were recorded by use of a CEZ-2300 patch clamp amplifier (Nihon Kohden, Tokyo), with the current filtered $(-3 \mathrm{~dB}$, four-pole Bessel filter) at $1 \mathrm{kHz}$. Data were digitized at sampling rates of $10 \mathrm{kHz}$ by use of a TL-125 kHz interface (Scientific Solutions). The analysis routines used a pClamp (version 5.5.1, Axon Instruments) to determine distributions for channel amplitudes and open and closed times. An automated 50\% threshold crossing routine was used to detect channel transition, and all data were obtained at room temperature $\left(20-22^{\circ} \mathrm{C}\right)$. The data in the text were expressed as mean $\pm \mathrm{SD}$.

\section{RESULTS}

The channel recorded was highly selective for $\mathrm{K}^{+}$, because its current-voltage relation reversed at $3.2 \pm 2.3$ $\mathrm{mV}(n=18)$, very close to the equilibrium potential for potassium ion $\left(E_{\mathrm{K}}\right)$, with symmetrical $\mathrm{K}^{+}(140 /$ $140 \mathrm{mmol} / l$ ) and the reversal potential shifted in a negative direction to $-59.8 \pm 9.2 \mathrm{mV}(n=18)$ with a low concentration of $\mathrm{K}^{+}(5 \mathrm{mM})$ in the pipette. A similar observation was also reported in neocortical pyramidal neurons [12]. The activities of the channel recorded were affected by $\mathrm{Ca}^{2+}$ concentrations at the intracellular membrane surface, $\left[\mathrm{Ca}^{2+}\right]_{i}$, of excised membrane patches. Whereas submicromolar concentrations of $\mathrm{Ca}^{2+}$ at the inner membrane surface were sufficient to activate the $\mathrm{BK}_{\mathrm{Ca}}$ channel, $100 \mu \mathrm{M} \mathrm{Ca}^{2+}$ at the extracellular membrane surface activated no channels at any membrane potentials tested in this study (from $-50 \mathrm{mV}$ to $+50 \mathrm{mV}$ ). Current-voltage relations indicated that the channel had high unitary conductance of approximately $245 \mathrm{pS}$. These three points served as keys to identification of the channel recorded as the $\mathrm{BK}_{\mathrm{Ca}}$ channel.

Besides the $\mathrm{BK}_{\mathrm{Ca}}$ channel, the membrane patches typically contained other channels with smaller conductance (or smaller conductances) than that of the 
$\mathrm{BK}_{\mathrm{Ca}}$ channel. These additional channels with smaller conductance will not be considered in this paper, and we have typically selected records in which they are not obviously present.

We also found an inactivation of $\mathrm{BK}_{\mathrm{Ca}}$ channels as described by Hicks et al. [28]. To remove the inactivation of $\mathrm{BK}_{\mathrm{Ca}}$ channels recorded at depolarization, all recordings at membrane depolarization were preceded by a hyperpolarization step of $-60 \mathrm{mV}$ for at least 1 min.

To determine the unitary conductance of $\mathrm{BK}_{\mathrm{Ca}}$ channel, we measured amplitudes of the single channel current at various membrane potentials, and the unitary conductance of $\mathrm{BK}_{\mathrm{Ca}}$ channel was determined by fitting a regression line through the data points. Examples of these currents evoked at varying membrane potentials were shown in Fig. 1A from an inside-out configuration of an adult pyramidal neuron in CA1 region with $0.1 \mu \mathrm{M}\left[\mathrm{Ca}^{2+}\right]_{i}$. The greater the amplitude of the membrane potential, the greater the amplitude of the outward current. With symmetrical $\mathrm{K}^{+}(140 /$ $140 \mathrm{mM}$ ) in both the pipette and the bath solutions, the reversal potential was close to $0 \mathrm{mV}$. The current-voltage relationship was plotted in Fig. 1B. The currentvoltage relationships were fitted with a straight line having a slope conductance of $245.4 \pm 19.1 \mathrm{pS}$ (Fig. 1B). The channel showed no rectification at all membrane potentials tested.

An individual $P_{0}-V$ curve was fitted with the Boltzmann equation $P_{\mathrm{o}}=P_{\mathrm{o}, \max } /\left\{P_{\mathrm{o}, \max }+\exp \left[(1 / K)\left(V_{1 / 2}-V\right)\right]\right\}$ with $2 \mu \mathrm{M}\left[\mathrm{Ca}^{2+}\right]_{\mathrm{I}}$, and the voltage dependence of the $\mathrm{BK}_{\mathrm{Ca}}$ channel was determined. The equation was transformed into the logarithmic form, $V=V_{1 / 2}+K \times \ln \left\{P_{\mathrm{o}}\right\}$ $\left.\left[P_{\mathrm{o}, \max }\left(1-P_{\mathrm{o}}\right)\right]\right\}$, where $K$ is the membrane depolarization for an $e$-fold increase in $P_{\mathrm{o}}$ and $V_{1 / 2}$ is the patch potential at which $P_{\mathrm{o}}$ is half the maximum $P_{\mathrm{o}}\left(P_{\mathrm{o}, \max }\right)$. $V_{1 / 2}$ and $K$ could be obtained by plotting $\ln \left\{P_{\mathrm{o}} /\left[P_{\mathrm{o}, \max }\right.\right.$ $\left.\left.\left(1-P_{\mathrm{o}}\right)\right]\right\}$ against voltage (Fig. 2). The values of $V_{1 / 2}$ and $K$ were 2.6 and $17.0 \mathrm{mV}$, respectively, indicating that $P_{\mathrm{o}}$ of $\mathrm{BK}_{\mathrm{Ca}}$ channel increases $e$-fold for each 17.0 \pm $0.7 \mathrm{mV}(n=10)$ positive change in membrane potential.

To further demonstrate the sensitivity of the $\mathrm{BK}_{\mathrm{Ca}}$ channel to $\left[\mathrm{Ca}^{2+}\right]_{\mathrm{i}}$, recordings were obtained with different $\mathrm{Ca}^{2+}$ concentrations at the cytosolic face of the excised membrane. Figure 3 plotted the relationship between $P_{\mathrm{o}}$ and $\left[\mathrm{Ca}^{2+}\right]_{\mathrm{i}}$. In constructing this plot data with each $\left[\mathrm{Ca}^{2+}\right]_{\mathrm{i}}$ we averaged the data from 20 different membrane patches. At a membrane potential of $+20 \mathrm{mV}$, the open probability of a $\mathrm{BK}_{\mathrm{Ca}}$ channel increased to $83.3 \%$, from $0.0056 \%$, as $\left[\mathrm{Ca}^{2+}\right]_{\mathrm{i}}$ increased to $100 \mu \mathrm{M}$, from $0.01 \mu \mathrm{M}$. It was shown in Fig. 3 that there was a steep relationship between open probability vs. $\left[\mathrm{Ca}^{2+}\right]_{\mathrm{i}}$ over a range of 0.5 to $5 \mu \mathrm{M}$ and that the
A

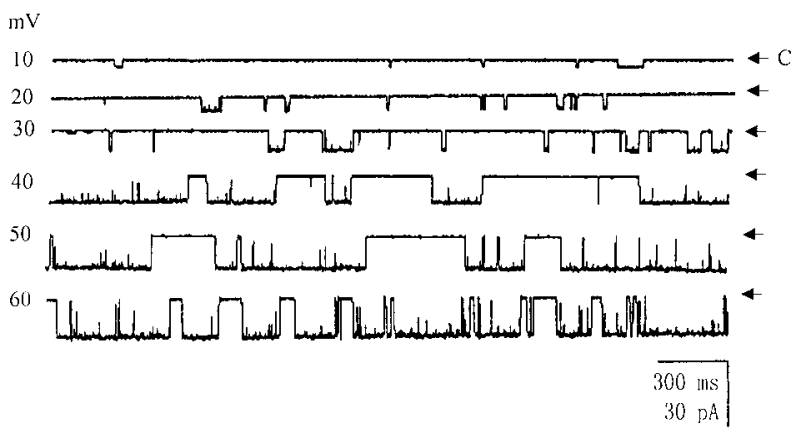

$\mathrm{B}$

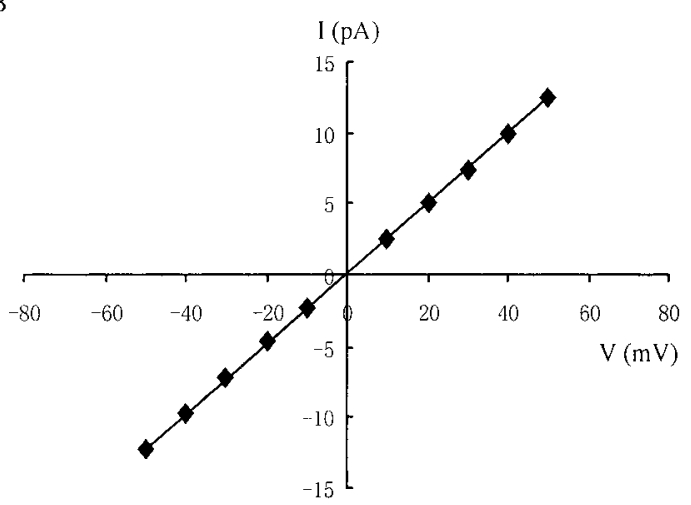

Fig. 1. Voltage dependence of the $\mathrm{BK}_{\mathrm{Ca}}$ channel activity in an excised, inside-out patch of somatic membrane from hippocampal CA1 pyramidal neurons of adult rat.

A: Segments of single-channel records showing $\mathrm{K}^{+}$currents through a single $\mathrm{BK}_{\mathrm{Ca}}$ channel at varying membrane potentials in symmetrical $140 \mathrm{mM} \mathrm{K}^{+}$solutions (excised, inside-out configuration) with $2 \mu \mathrm{M}\left[\mathrm{Ca}^{2+}\right]_{\mathrm{i}}$. From the top trace to the bottom, the membrane potential was $+10,+20,+30$, $+40,+50$, and $+60 \mathrm{mV}$, respectively. The outward currents evoked are shown as downward deflections. B: Plots of single channel current amplitudes ( $/$ ) against membrane potentials $(V)$. The line fitted to the data points gave a slope conductance of approximately $245 \mathrm{pS}$.

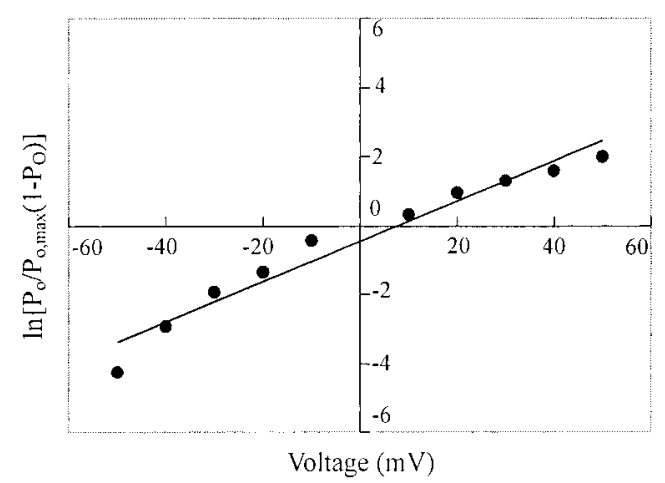

Fig. 2. Quantitative analysis of voltage dependence of BK $\mathrm{Ca}_{\mathrm{a}}$ channel. Logarithmic Boltzmann fittings of $\boldsymbol{P}_{\mathrm{o}}-V$ curve for representative single $\mathrm{BK}_{\mathrm{Ca}}$ channel from $\mathrm{CA} 1$ pyramidal neurons. 
slope of the relationship for lower or higher levels of $\left[\mathrm{Ca}^{2+}\right]_{\mathrm{i}}$ was reduced. The $\left[\mathrm{Ca}^{2+}\right]_{\mathrm{i}}$ at which the channel was half activated was $2 \mu \mathrm{M}$. Whereas $\left[\mathrm{Ca}^{2+}\right]_{\mathrm{i}}$ had pronounced effects on channel activity, it had little effect on single channel current amplitudes, which remained relatively constant for $\left[\mathrm{Ca}^{2+}\right]_{\mathrm{i}}$ ranging from 0.1 to $100 \mu \mathrm{M}$. Furthermore, single channel current amplitudes appeared to remain constant to $0.01 \mu \mathrm{M}$ $\left[\mathrm{Ca}^{2+}\right]_{i}$ if the limited frequency response of the patch clamp was taken into account by measuring only those currents where the channels were open sufficiently long enough for the recording system to record the peak current.

A detailed kinetic analysis was usually precluded by the presence of multiple active channels in the patch. Figure 4 showed detailed kinetic data from a patch in which only a single channel was observed with $2 \mu \mathrm{M}\left[\mathrm{Ca}^{2+}\right]_{\mathrm{i}}$ with membrane potential of +20 $\mathrm{mV}$. In general, the open time distribution was fitted satisfactorily with a double exponential function. This

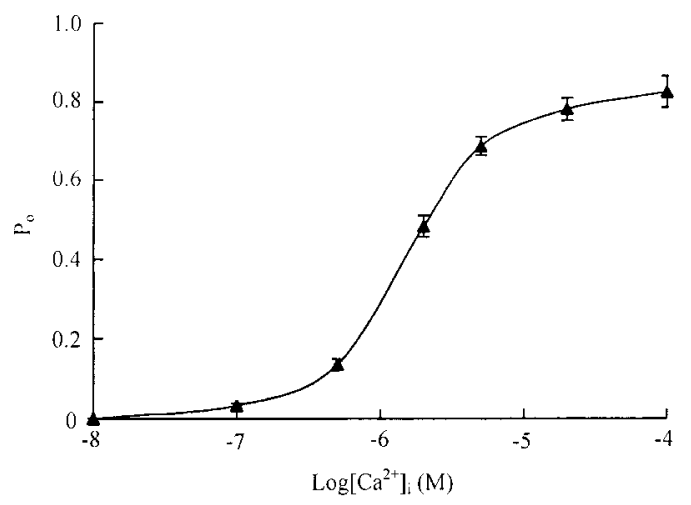

Fig. 3. Effects of $\left[\mathrm{Ca}^{2+}\right]_{i}$ on $\mathrm{BK}_{\mathrm{Ca}}$ channel activity in excised membrane patches. Plots of $P_{\mathrm{o}}$ of $\mathrm{BK}_{\mathrm{Ca}}$ channel against $\log \left[\mathrm{Ca}^{2+}\right]_{\text {. }}$. One hundred percent indicates that $\mathrm{BK}_{\mathrm{Ca}}$ channel was continuously open. Membrane potential, $+20 \mathrm{mV} ; 100 \mu \mathrm{M}\left[\mathrm{Ca}^{2+}\right]_{\mathrm{o}}$. Note that $P_{\mathrm{o}}$ with each $\left[\mathrm{Ca}^{2+}\right]_{\mathrm{i}}$ was averaged from 20 different membrane patches. was shown in Fig. 4A, in which the open time histogram is plotted for $2 \mu \mathrm{M}\left[\mathrm{Ca}^{2+}\right]_{\mathrm{i}}$. The histogram was fitted with a double exponential with the time constant of $2.8 \pm 2.1$ and $19.2 \pm 10.1 \mathrm{~ms}(n=15)$. The closed time distribution also required a double exponential for a reasonable fit (Fig. 4B) with the time constant of $2.7 \pm 1.6$ and $26.9 \pm 17.9 \mathrm{~ms}(n=15)$.

Figure 5 presented records in which the channel appeared to enter a conductance state (indicated by dots) in which the current through a single channel was about $45 \%$ of normal. Reduced single channel currents of this type were observed in 13 of 147 experiments. Openings with reduced current amplitude typically comprised less than $0.3 \%$ of the total channel open time and had little effect on the result in the previous sections. It seemed impossible that this apparent reduced conductance state arose from a separate channel with $45 \%$ amplitude of $\mathrm{BK}_{\mathrm{Ca}}$ channel, since such a

$$
\text { A }
$$

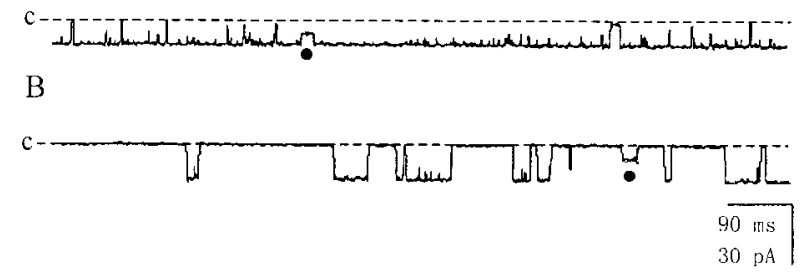

Fig. 5. Multiple conductance states of $\mathrm{BK}_{\mathrm{Ca}}$ channel. Segments of records of membrane currents with normal and reduced (dots) single-channel current amplitudes. Reduced current amplitude was $40 \%$ of normal. Outward currents evoked were shown as downward deflections. A: A trace showing a reduced conductance state appeared to be entered directly from an open channel state of normal conductance without passing through an obvious closed channel state. Membrane potential, $+40 \mathrm{mV} ; 5 \mu \mathrm{M}\left[\mathrm{Ca}^{2+}\right]_{\mathrm{i}}$. B: A trace showing a reduced conductance state recorded between apparently closed channel states. Membrane potential, $+60 \mathrm{mV} ; 0.1 \mu \mathrm{M}\left[\mathrm{Ca}^{2+}\right]_{\mathrm{i}}$. The calibration in B also applied to $\mathrm{A}$.
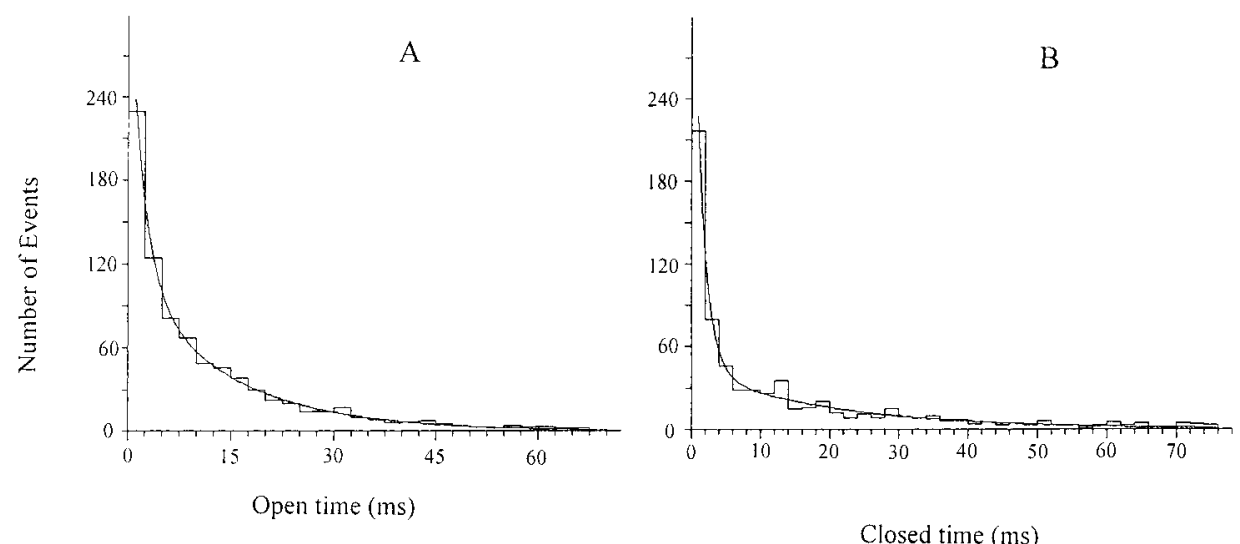

Fig. 4. Representative distributions of single $\mathrm{BK}_{\mathrm{Ca}}$ channel characteristics. A: Open distribution of a single $\mathrm{BK}_{\mathrm{Ca}}$ channel recorded at membrane potential of $+20 \mathrm{mV}$ in the presence of $2 \mu \mathrm{M}\left[\mathrm{Ca}^{2+}\right]_{\text {i. }}$. The distribution was fitted with a two-exponential function with a time constant of $2.1 \mathrm{~ms}$ and $14.4 \mathrm{~ms}$. B: A closed distribution of a single $\mathrm{BK}_{\mathrm{Ca}}$ channel in the same conditions as in A. The closed distribution was fitted with a twoexponential function with a time constant of $1.5 \mathrm{~ms}$ and $21.5 \mathrm{~ms}$. 


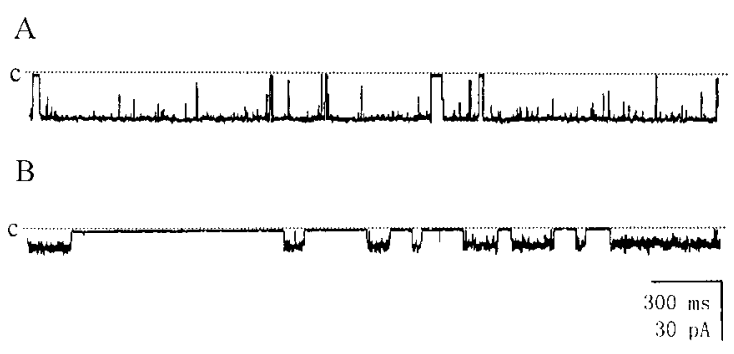

Fig. 6. Effects of external TEA on $\mathbf{B K}_{\mathrm{Ca}}$ channel. Note that each trace was from different membrane patches. With $0.5 \mathrm{mM}$ TEA in the pipette solution, $\mathrm{BK}_{\mathrm{Ca}}$ channel's apparent unit current amplitude was reduced (B) compared with normal $(\mathbf{A})$ by rapid blocking events that could not be resolved. Outward currents evoked were shown as downward deflections. Membrane potentials, $+80 \mathrm{mV}$; $\left[\mathrm{Ca}^{2+}\right]_{i}, 0.5 \mu \mathrm{M}$. The calibration in $B$ also applied to $A$.

channel was not observed in isolation.

The $\mathrm{BK}_{\mathrm{Ca}}$ channel was quite sensitive to a low concentration $(0.5 \mathrm{mM})$ of external TEA, a $\mathrm{K}^{+}$channel blocker (TEA was included in the pipette solution, Fig. 6). The 2 recordings in Fig. 6 were from different patches, but the apparent conductance of the channel was reduced in the presence of TEA (Fig. 6B). The most likely explanation for the reduction in conductance by TEA was a rapid, unresolved block (note the increased noise during channel openings), which caused an apparent decrease in the unit current amplitude. The $\mathrm{BK}_{\mathrm{Ca}}$ channel was not affected by the administration of TEA to the intracellular side of membrane at either membrane potential tested.

\section{DISCUSSION}

The properties of $\mathrm{BK}_{\mathrm{Ca}}$ channel was examined in excised membrane patches of hippocampal CA1 pyramidal neurons from adult rat by use of an inside-out configuration of patch clamp techniques. We found that the open frequency of the channel and open probability increased with increasing $\left[\mathrm{Ca}^{2+}\right]_{\mathrm{i}}$ and/or depolarization. The observed open distribution of $\mathrm{BK}_{\mathrm{Ca}}$ channel was described by the sum of two exponentials, and the channel occasionally entered a state with a single channel current $45 \%$ of the normally observed single $\mathrm{BK}_{\mathrm{Ca}}$ channel current amplitude.

This paper also provided evidence that pyramidal neurons in hippocampal CA1 region from adult rats has a large conductance $\mathrm{Ca}^{2+}$-activated $\mathrm{K}^{+}$channel that is activated by intracellular $\left[\mathrm{Ca}^{2+}\right]_{\mathrm{i}}$. Although the conductance of a $\mathrm{BK}_{\mathrm{Ca}}$ channel in adult hippocampal CA1 pyramidal neurons ( $245 \mathrm{pS})$ was slightly higher than in cultured hippocampal neurons $(220 \mathrm{pS})$, the $\mathrm{BK}_{\mathrm{Ca}}$ channel in hippocampal neurons ([8-11], the present study) has properties similar to those that have been reported in other cell types, namely, large conductance (approximately $200 \mathrm{pS}$ ), voltage dependence, and sensitivities to $\left[\mathrm{Ca}^{2+}\right]_{\mathrm{i}}$ or external TEA $[2-4,6,7$, $19,27]$.

The $\left[\mathrm{Ca}^{2+}\right]_{\mathrm{i}}$ concentration in the resting CA1 pyramidal neurons is estimated as $100 \mathrm{nM}$, and this increases to $500-600 \mathrm{nM}$ after the action potential. In some pathological conditions, such as forebrain ischemia, it may reach as high as $1-2 \mu \mathrm{M}[29,30]$. Our results showed a steep relationship between open probability between $\left[\mathrm{Ca}^{2+}\right]_{\mathrm{i}}$ over the range between 0.5 and $5 \mu \mathrm{M}$, and the slope of the relationship for lower or higher levels of $\left[\mathrm{Ca}^{2+}\right]_{\text {i }}$ was reduced (Fig. 3). The activities of the $\mathrm{BK}_{\mathrm{Ca}}$ channel were first observed at $0.01 \mu \mathrm{M}$ of $\left[\mathrm{Ca}^{2+}\right]_{\mathrm{i}}$ and increased with $\left[\mathrm{Ca}^{2+}\right]_{\mathrm{i}}$. The $\left[\mathrm{Ca}^{2+}\right]_{\mathrm{i}}$ at which $P_{\mathrm{o}}$ of the channel is 0.5 was $2 \mu \mathrm{M}$. Previous data from cultured hippocampal neurons showed that the steep relationship between open probability vs. $\left[\mathrm{Ca}^{2+}\right]_{\mathrm{i}}$ was from about 1 to $10 \mu \mathrm{M}$; the activity was first observed at $1 \mu \mathrm{M}\left[\mathrm{Ca}^{2+}\right]_{\mathrm{i}}$; and the $\left[\mathrm{Ca}^{2+}\right]_{\mathrm{i}}$ at which $P_{\mathrm{o}}$ of the channel is 0.5 was $4 \mu \mathrm{M}$ [8]. Studies on newborn hippocampal neurons observed that $14.54 \mu \mathrm{M}$ are required to activate $\mathrm{BK}_{\mathrm{Ca}}$ channels with $P_{\mathrm{o}}$ of 0.5 [10]. Meanwhile, the present study showed that $P_{\mathrm{o}}$ of $\mathrm{BK}_{\mathrm{Ca}}$ channel increases $e$-fold for each $17.0 \mathrm{mV}$ positive change in membrane potential, less than $22 \mathrm{mV}$ in cultured hippocampal neurons [11]. Taken together, it is implied that the $\mathrm{BK}_{\mathrm{Ca}}$ channel in adult hippocampal neurons is more dependent on voltage and more sensitive to $\left[\mathrm{Ca}^{2+}\right]_{\mathrm{i}}$ than in cultured or newborn hippocampal neurons.

The present study exhibited that two exponential functions were required to describe the open distribution of the $\mathrm{BK}_{\mathrm{Ca}}$ channel (Fig. $4 \mathrm{~A}$ ) and that the $\mathrm{BK}_{\mathrm{Ca}}$ channel occasionally entered an open state with a single channel current amplitude of $45 \%$ of the normally observed single channel current amplitude (Fig. 5), suggesting at least three open channel states of the $\mathrm{BK}_{\mathrm{Ca}}$ channel in adult hippocampal CA1 pyramidal neurons, namely, two states of an apparently normal conductance with different mean open times and a third with a reduced conductance. All three states were observed in current records from a patch containing only a single channel, indicating that a single $\mathrm{BK}_{\mathrm{Ca}}$ channel can enter all three open channel states. But only one open state was observed in cultured or neonatal hippocampal neurons [8-10].

In our records a reduced conductance state appeared to enter directly from an open channel state of normal conductance without passing through an obvious closed channel state; it then returned directly to the normal conducting state before closing fully (Fig. $5 \mathrm{~A})$. This observation suggested that the reduced con- 
ductance state is in series with a normal conducting state. However, we did not exclude the possibility that the reduced conductance state was preceded and followed by a closed channel state too brief to be detected by our recording system. This phenomenon was also found in cultured muscle [3]. Labarca and Miller [31] had observed the existence of two conductance states observed in a $\mathrm{K}^{+}$channel from sarcoplasmic reticulum; in their preparation, however, the reduced conductance state was preceded and followed by the higher conductance state. The existence of several conducting states had been reported in an acetylcholine-activated channel [32]. It is found that the reduced conducting state is preceded, but not followed, by the higher conductance state. Meanwhile, a reduced conductance state was also recorded between apparently closed channel states in our results (Fig. 4B). The reduced conductance channel state was not observed in cultured or newborn hippocampal neurons [8-11].

$\mathrm{BK}_{\mathrm{Ca}}$ channels play crucial roles in the regulating of fAHP and the duration of action potential [14, 18-21], and a previous study had demonstrated a decrease in the duration of action potential with age in hippocampal CA1 neurons [33]. Therefore, the properties of $\mathrm{BK}_{\mathrm{Ca}}$ channels in adult rat reported in the present study, more dependence on voltage and more sensitivity to intracellular calcium than in neonatal rat, may contribute to the shortened duration in action potential of hippocampal CA1 neurons from adult rat.

This research is supported by grants to Tian-Ming Gao from the National Natural Science Foundation of P.R. China (NNSF 39970265), the Outstanding Scientists Program of PLA (01J009), and the Team Collaboration Project of Guangdong (No. 10717).

\section{REFERENCES}

1. Marty A: Ca-dependent $K$ channels with large unitary conductance in chromaffin cell membranes. Nature 291: 497-500, 1981

2. Pallotta BS, Magleby KL, and Barrett JN: Sinlge channel recordings of $\mathrm{Ca}^{2+}$-activated $\mathrm{K}^{+}$currents in rat muscle cell culture. Nature 293: 471-474, 1981

3. Barrett JN, Magleby KL, and Pallotta BS: Properties of single calcium-activated potassium channels in cultured rat muscle. J Physiol (Lond) 331: 211-230, 1982

4. Wong BS, Lecar $\mathrm{H}$, and Adler M: Single calcium dependent potassium channels in clonal anterior pituitary cells. Biophys J 39: 313-317, 1982

5. Thompson SH: Three pharmacologically distinct potassium channels in molluscan neurones. J Physiol (Lond) 265: 465-488, 1977

6. Adams PR, Constantt A, Brown DA, and Clark RB: Intracellular $\mathrm{Ca}^{2+}$ activates a fast voltage-sensitive $\mathrm{K}^{+}$ current in vertebrate sympathetic neurons. Nature 296:
746-749, 1982

7. Smart, TG: Single calcium-activated potassium channels recorded from cultured rat sympathetic neurons. J Physiol (Lond) 389: 337-360, 1987

8. Franciolini F: Calcium and voltage dependence of single $\mathrm{Ca}^{2+}$-activated $\mathrm{K}^{+}$channels from cultured hippocampal neurons of rat. Biochim Biophys Acta 943: 419427, 1988.

9. Lancaster B, Nicoll RA, and Perkel DJ: Calcium activates two types of potassium channels in rat hippocampal neurons in culture. J Neurosci 11: 23-30, 1991

10. Yoshida A, Oda M, and Yoshimi I: Kinetics of the $\mathrm{Ca}^{2+}$ activated $\mathrm{K}^{+}$channel in rat hippocampal neurons. Jpn J Physiol 41: 297-315, 1991

11. Wann KT and Richards CD: Properties of single calcium-activated potassium channels of large conductance in rat hippocampal neurons in culture. Eur $\mathrm{J}$ Neurosci 6: 607-617, 1994

12. Kang J, Huguenard JR, and Prince DA: Development of BK channels in neocortical pyramidal neurons. J Neurophysiol 76: 188-198, 1997

13. Wang G-Y, Robinson DW, and Chalupa LM: Calciumactivated potassium conductances in retinal ganglion cells of the ferret. J Neurophysiol 79: 151-158, 1997

14. Schwindt PC, Spain WJ, Foehring RC, Stafstrom CE, Chubb MC, and Crill WE: Multiple potassium conductances and their function in neurons from cat sensorimotor cortex in vitro. J Neurophysiol 59: 424-449, 1988

15. Sah $\mathrm{P}: \mathrm{Ca}^{2+}$-activated $\mathrm{K}^{+}$currents in neurons: types, physiological roles and modulation. TINS 19: 150-154, 1996

16. Lancaster B and Nicoll RA: Properties of two calciumactivated hyper-polarizations in rat hippocampal neurones. J Physiol (Lond) 389: 187-204, 1986

17. Storm JF: Action potential repolarization and a fast after-hyperpolarization in ra hippocampal pyramidal cells. J Physiol (Lond) 385: 733-759, 1987

18. Storm JF: Potassium currents in hippocampal pyramidal cell. In: Progree in Brain Research, Elsevier Science BV (Biomedical Division), Vol 83, pp 161-187, 1990

19. Iwatsuki $\mathrm{N}$ and Petersen OM: Action of tetraethylammonium ion on calcium-activated potassium channels in pig pancreatic acinar cells studied by patch-clamp single-channel and whole-cell current recording. J Membr Biol 86: 139-144, 1985

20. Lancaster B, Madison DV, and Nicoll DA: Charybdotoxin selectively blocks a fast, Ca-dependent afterhyperpolarization (AHP) in hippocampal pyramidal cells. Soc Neurosci Abstr 12: 560, 1986

21. Storm JF: Intracellular injection of a $\mathrm{Ca}^{2+}$ chelator inhibits spike repolarization in hippocampal neurons. Brain Res 345: 387-392, 1987

22. Storm JF: Calcium-dependent spike repolarization, and three kinds of afterhyperpolarization (AHP) in hippocampal pyramidal cells. Soc Neuronsci Abstr 11: 1183, 1985

23. Bargas J, Howe A, Eberwine J, Cao Y, and Surmeier DJ: Cellular and molecular characterization of $\mathrm{Ca}^{2+}$ currents in acutely-isolated, adult rat neostriatal neurons. J Neurosci 14: 6667-6686, 1994

24. Surmeier DJ, Bargas J, Hemmings HC Jr, Nairn AC, 


\section{Properties of BK Channels in CA1 Neurons}

Greengard P: Modulation of calcium currents by a D1 dopaminergic protein kinase/phosphatase cascade in rat neustriatal neurons. Neuron 14: 385-397, 1995

25. Gong LW, Gao TM, Huang H, and Tong Z: Redox modulation of large conductance calcium-activated potassium channels in CA1 pyramidal neurons from adult rat hippocampus. Neurosci Lett 286: 191-194, 2000

26. Hamill OP, Marty A, Neher E, Sakmann B, and Sigworth FJ: Improved patch clamp techniques for high resolution current recording from cells and cell free membrane patches. Pflügers Arch 391: 85-100, 1981

27. Magleby KL and Pallotta BS: Calcium dependence of open and shut interval distributions from clacium-activated potassium channels in cultured rat muscle. J Physiol (Lond) 344: 585-604, 1983

28. Hicks GA and Marrion NV: $\mathrm{Ca}^{2+}$-dependent inactivation of large conductance $\mathrm{Ca}^{2+}$-activated $\mathrm{K}^{+}(\mathrm{BK})$ channels in rat hippocampal neurons produced by pore block from an associated particle. J Physiol (Lond) 508: 721734, 1998
29. Silver IA and Erecinska M: Intracellular and extracellular changes of $\left[\mathrm{Ca}^{2+}\right]_{i}$ in hypoxia and ischemia in rat brain in vivo. J Gen Physiol 95: 837-866, 1990

30. Nakamura $T$, Minamisawa $H$, Katayama $Y$, Ueda $M$, Terashi A, Nakamura K, and Kudo Y: Increased intracellular $\mathrm{Ca}^{2+}$ concentration in the hippocampal CA1 area during global ischemia and reperfusion in the rat: a possible cause of delayed neuronal death. Neuroscience 88: 57-67, 1999

31. Labarca PP and Miller C: $\mathrm{A} \mathrm{K}^{+}$selective, three-state channel from fragmented sarcoplasmic reticulum of frog leg muscle. J Membr Biol 61: 31-38, 1985

32. Hamill OP and Sakmann B: Multiple conductance states of single acetylcholine receptor channels in embryonic muscle cells. Nature 294: 462-464, 1981

33. Spigelman I, Zhang L, and Carlen PL: Patch-clamp study of postnatal development of CA1 neurons in rat hippocampal slices: membrane excitability and $\mathrm{K}^{+}$current. J Neurophysiol 68: 55-67, 1992 